\title{
PELATIHAN EKONOMI SYARIAH BAGI GURU SMK SEBAGAI INISIASI PEMBUKAAN PROGRAM STUDI PERBANKAN SYARIAH
}

\author{
Hasan Mukhibad dan Prabowo Yudo Jayanto \\ Jurusan Akuntansi, Fakultas Ekonomi, Universitas Negeri Semarang \\ Email : hasanmukhibad@mail.unnes.ac.id
}

\begin{abstract}
The development of Islamic banking industry is rapid. Data from Indonesian Bank shows the growth of asset annually (YoY) are $33.49 \%$. This rapid growth brings the consequences of increasingly needed of Human Resources who understand the concept, practical and operationalization of Islamic bank. Nevertheless, the results of Indonesian's Bank research showing that there are $90 \%$ of Islamic bank employees do not has Islamic economic background. To meet the needs of this human resources, some vocational high schools (Sekolah Menengah Kejuruan) already has expertise program in Islamic bank. However, the Collage of Education in Indonesia does not yet has a department of Islamic Economic Education or a similar study program that produces a teacher of Islamic bank. Synergy between collage and teachers is needed to increase the teachers competence in teaching in Islamic Bank. This community service program done to improve understanding of teachers by conducting training in Demak District. Training materials related to the concept of Islamic economy, operationalization of Islamic banks and accounting. Based on data using a different test T-Test yielded a significance value are 0.000 . This result that this training provides benefits of improving teachers' understanding of Islamic economy.
\end{abstract}

Keyword: Islamic Bank, SMK Banking Syariah, Vocational High Schools, Human Research, Training

\section{PENDAHULUAN}

Perkembangan lembaga

keuangan syariah didunia merupakan salah satu lembaga keuangan yang paling pesat perkembangannya di Dunia (http://www.adb.org/sectors/finance/isla mic-finance). Kustin (2015) menilai bahwa perkembangan lembaga keuangan syariah di dunia mencapai 14\% pertahun. Khan (2008) menprediksikan total asset Islamic Banking Industry (IBIs) pada tahun 2012 adalah sebesar US\$ 1,60 milyar, sedangkan Ernst \& Young mengestimasikan bahwa jumlah aset lembaga keuangan syariah mencapai USD 3.4 milyar pada tahun 2018 .

Di Indonesia, Iqbal dan Mirakhor (2013) mencatat bahwa perkembangan perbankan syariah di Indonesia mencapai $15 \%$ sampai dengan 20\% pertahun. Namun demikian, outlock Perbankan Syariah tahun 2015 menunjukkan bahwa ratarata pertumbuhan aset bank syariah years on years (YoY) 33,49 \%. Bank 
Indonesia dalam laporan tahunannya menjelaskan bahwa perbankan syariah di Indonesia mengalami peningkatan, baik secara kelembagaan, total asset, jumlah nasabah, dan market share-nya (Anisykurlillah et al, 2015). Berikut adalah perkembangan asset bank syariah di Indonesia.

Tabel 1. Perkembangan Aset Perbankan syariah (Year on Year)

\begin{tabular}{|c|c|c|c|}
\hline No & Tahun & $\begin{array}{c}\text { Jumlah Aset } \\
\text { (Milyar Rp) }\end{array}$ & $\begin{array}{c}\text { Perkembangan } \\
\text { (Yoy) }\end{array}$ \\
\hline 1 & 2008 & 49.555 & - \\
\hline 2 & 2009 & 66.090 & $33.37 \%$ \\
\hline 3 & 2010 & 97.519 & $47.55 \%$ \\
\hline 4 & 2011 & 145.467 & $49.17 \%$ \\
\hline 5 & 2012 & 195.018 & $34.06 \%$ \\
\hline 6 & 2013 & 242.276 & $24.23 \%$ \\
\hline 7 & 2014 & 272.343 & $12.41 \%$ \\
\hline 8 & Juni, 2015 & 272.389 & $0,02 \%$ \\
\hline & Rata-rata & $\mathbf{1 5 2 . 6 1 0}$ & $\mathbf{3 6 , 4 7 \%}$ \\
\hline
\end{tabular}

Sumber : Statistik Perbankan Syariah Tahun 2015 - Diolah

Perkembangan industri

perbankan syariah yang sangat pesat di atas, sebenarnya masih dibawah target yang ditetapkan BI, yakni belum mencapai market share $5 \%$ dari perbankan di Indonesia. Direktur Utama Bank Syariah Mandiri, Yuslam Fauzi mengemukakan bahwa salah satu tantangan bank syariah adalah masih terbatasnya kompetensi sumberdaya manusia (man power) (2005). Hasil riset Universitas Indonesia pada tahun 2003 menunjukkan bahwa selama ini, 90\% SDM bank syariah tidak memiliki latar belakang pendidikan ekonomi syariah (Amalia dan Al Arif, 2013).
Kendala-kendala tersebut di atas menjadi alasan beberapa lembaga pendidikan di tingkat perguruan tinggi maupun sekolah kejuruan (SMK) membuka program studi ekonomi syariah, perbankan syariah, akuntansi syariah atau prodi sejenis lainnya. Pembukaan prodi baru ini dilakukan untuk memenuhi kebutuhan SDM lembaga keuangan syariah yang meliputi perbankan syariah, asuransi syariah, pegadaian syariah, leasing syariah BMT, dan lembaga keuangan syariah lainnya.

Namun demikian, pembukaan prodi di atas, terutama di Sekolah Menengah Kejuruan (SMK) belum 
mampu sepenuhnya memecahkan masalah kebutuhan sumber daya manusia di bidang ilmu ekonomi syariah. Hal ini dikarenakan belum adanya perguruan tinggi di Indonesia (Lembaga Pendidikan Tinggi Kependidikan) yang mencetak guru ekonomi syariah. Akibatnya, selama ini kebutuhan guru SMK Perbankan Syariah berasal dari guru dengan latar belakang berbagai disiplin ekonomi.

Berdasarkan penjelasan permasalahan di atas, maka dapat disusun rumusan masalah dalam bentuk gambar berikut ini:

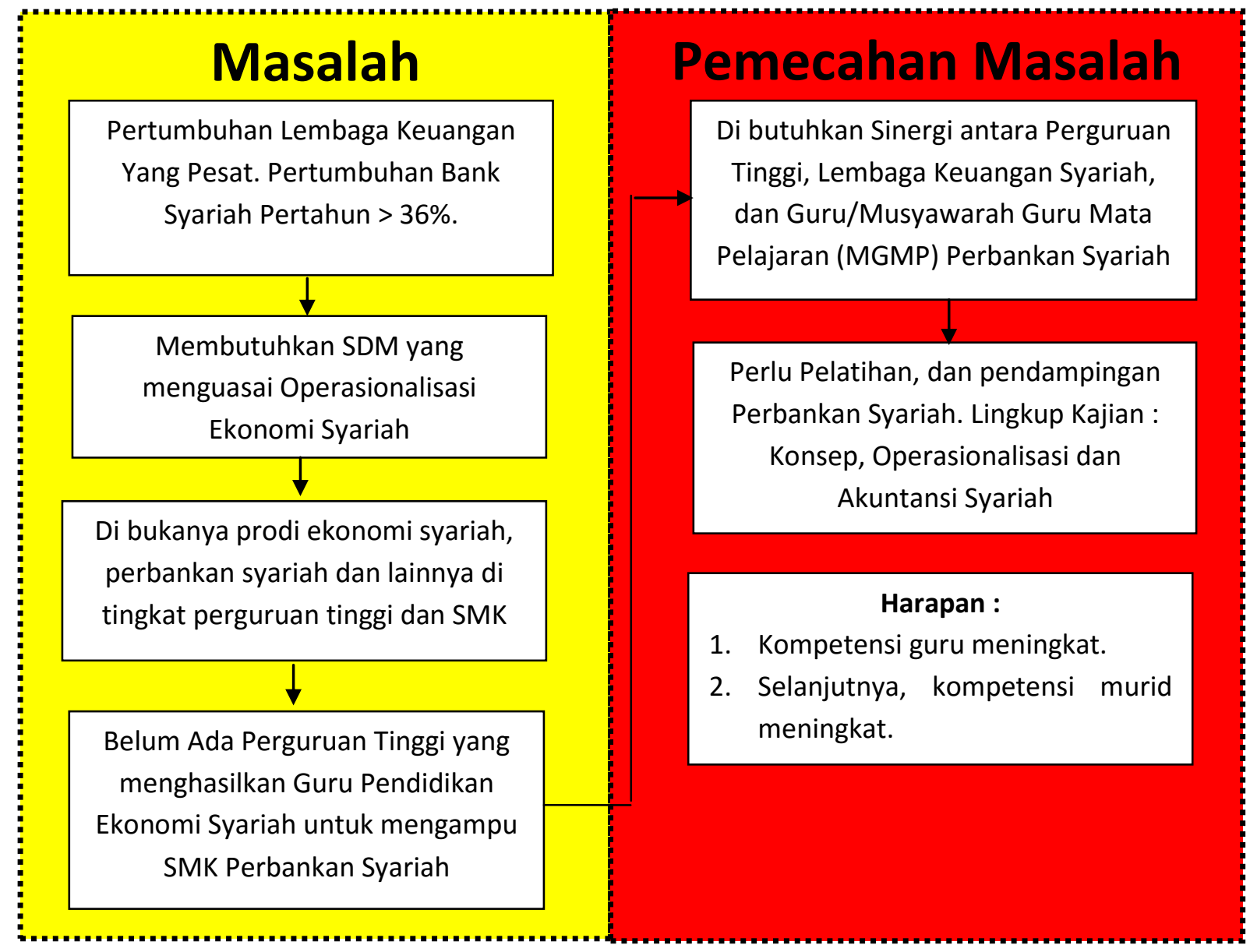

Gambar 1. Masalah dan Pemecahannya

\section{METODE PELAKSANAAN}

Permasalahan yang dihadapi mitra adalah belum optimalnya kompetensi guru SMK Perbankan Syariah. Hal ini dikarenakan belum adanya pendidikan tinggi yang menghasilkan guru pada SMK Perbankan Syariah.

Untuk memecahkan masalah ini, 
perlu diadakan pelatihan dan pendampingan untuk meningkatkan kompetensi guru. Sejumlah kompetensi yang akan ditransfer ke guru meliputi semua kompetensi yang harus ada pada guru Perbankan Syariah, yaitu kompetensi professional, pedagogic, kepribadian dan social.

Secara teknis, semua guru akan dievaluasi kompetensinya berdasarkan latar belakang pendidikan. Guru dengan latar belakang keguruan bidang ekonomi akan mendapat pelatihan yang berkaitan dengan keilmuan ekonomi syariah, akuntansi syariah, dan perbankan syariah. Guru dengan latar belakang pendidikan non keguruan bidang ekonomi syariah atau perbankan syariah akan memperoleh pelatihan yang berkaitan dengan ilmu pendidikan, seperti perencanaan pembelajaran, metode pengajaran, dan evaluasi pembelajaran.

Untuk mengevaluasi kegiatan pelatihan ini, akan diadakan penilaian sebelum dan sesudah (pre-test dan post test) dilakukan pelatihan. Penilaian ini dilakukan untuk menilai kemampuan peserta pelatihan. Hasil penilaian pretest dab post test ini akan dilakukan uji beda T-test sampel berhubungan dengan menggunakan alat bantu SPSS 21. Hasil pengujian menunjukkan adanya perbedaan jika uji T-test menghasilkan nilai signifikansi kurang dari 0,05 dan sebaliknya tidak terdapat perbedaan jika nilai signifikasi lebih dari 0,05 .

\section{KELAYAKAN PENGABDI}

Pelaksana kegiatan pengabdian ini adalah terdiri dai beberapa dosen yang memiliki keahlian dalam bidang ekonomi dan akuntansi syariah kontemporer dan dosen yang memiliki keahlian dalam operasionalisasi perbankan syariah dan lembaga keuangan syariah lainnya. Hal ini dilakukan untuk menunjang terwujudnya tujuan dari kegiatan.

Keterkaitan antara kompetensi tim, pembagian tugas, serta luaran yang dihasilkan serta keselaran dengan masalah yang dihadapi mitra tampak pada gambar berikut ini: 


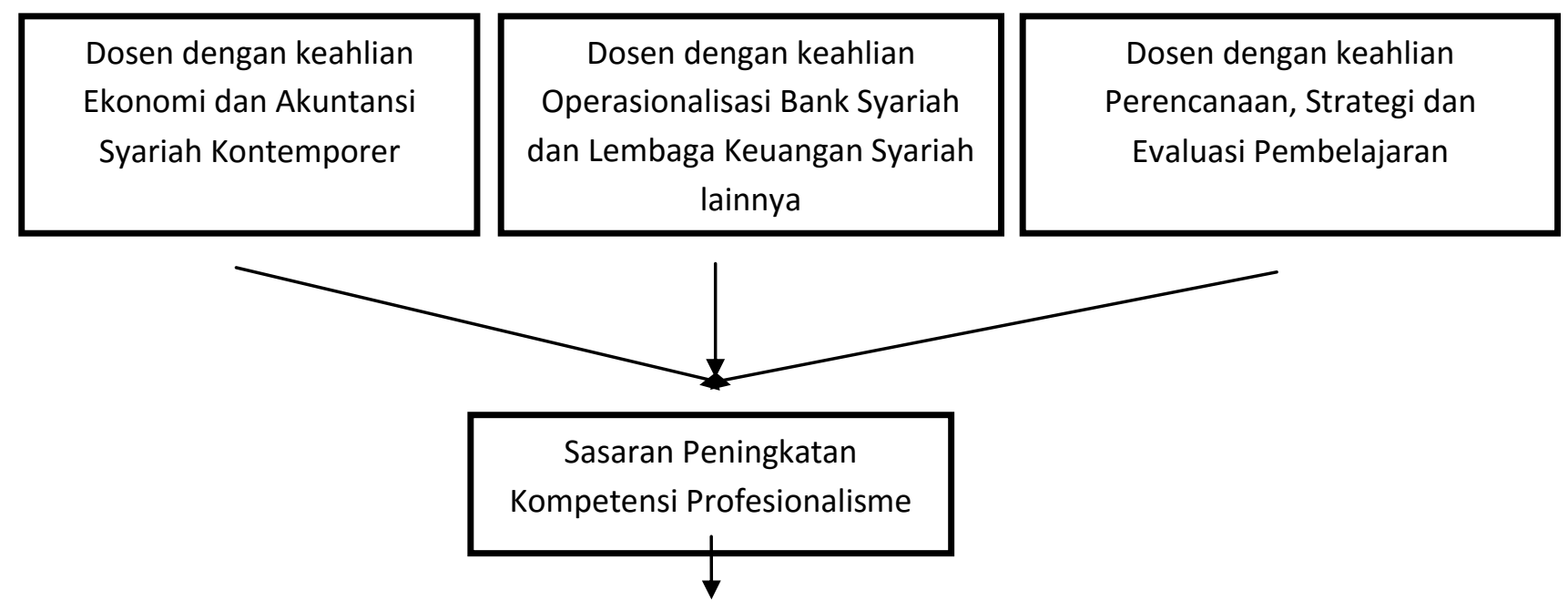

1. Guru memiliki kompetensi dalam mengajar bidang ekonomi syariah.

2. Siswa memiliki kompetensi / keahlian dalam operasionalisasi perbankan syariah

\section{Gambar 3}

Kompetensi Tim Pelaksana

\section{HASIL YANG DICAPAI}

Pelatihan ini diikuti oleh Guru SMK yang mengampu mata pelajaran berkaitan dengan ekonomi dan akuntansi yang tergabung dalam Musyawarah Guru Mata Pelajaran Akuntansi Kabupaten Demak. Peserta dari pelatihan ini sebanyak 12 orang dengan latar belakang pendidikan adalah Pendidikan Ekonomi atau Pendidikan Tata Niaga dan latar belakang pendidikan sejenis. Seluruh peserta berasal dari latar belakang pendidikan, sehingga materi kependidikan tidak dilakukan pada pelatihan ini.
Fokus pelatihan ini adalah materi terkait dengan konsep ekonomi syariah, operasionalisasi perbankan syariah dan akuntansi syariah. Materi konsep dari ekonomi syariah diberikan terkait dengan pandangan syariah dalam kehidupan berekonomi, termasuk di dalamnya transaksi ekonomi yang sesuai dengan syariah dan diakhiri dengan konsep riba. Pemberian materi ini sangat diperlukan sebagai dasar munculnya lembaga keuangan syariah.

$$
\text { Pelatihan operasionalisasi }
$$

perbankan syariah dilakukan dengan memberikan pemahaman beberapa akad atau produk pengganti bunga yang 
dijalankan oleh perbankan syariah. Produk yang diberikan adalah produk dalam penghimpunan dana dan penyaluran dana, meliputi akad mudharabah, musyarakah, murabahah, istishna, sama, dan ijarah.

Materi tentang akuntansi syariah yang dijelaskan dalam pelatihan ini adalah perkenalan dari Pedoman Standar Akuntansi Syariah (SAK Syariah) yang efektif tanggal 1 Januari 2017, yakni menyangkut kerangka dasar penyusunan laporan keuangan syariah, dan laporan keuangan syariah.

\section{Hasil Pre Test dan Post Test}

Pada evaluasi ini, tim pengabdi memberikan soal terkait dengan materi pelatihan kepada seluruh peserta. Soal akan dikerjakan oleh peserta pelatihan sebelum pelatihan (Pre test) dan setelah pelatihan (post test). Hasil penilaian pre test dan post test adalah sebagai berikut ini:

Tabel 1. Hasil Pre Test dan Post Test Peserta Pelatihan

\begin{tabular}{|c|c|c|}
\hline \multirow{2}{*}{ Guru Ke- } & \multicolumn{2}{|c|}{ Nilai } \\
\cline { 2 - 3 } & Pre Test & Post Tes \\
\hline 1 & 40 & 90 \\
\hline 2 & 50 & 70 \\
\hline 3 & 70 & 80 \\
\hline 4 & 50 & 80 \\
\hline 5 & 60 & 90 \\
\hline 6 & 70 & 100 \\
\hline 7 & 80 & 100 \\
\hline 8 & 30 & 70 \\
\hline 9 & 20 & 70 \\
\hline 10 & 30 & 70 \\
\hline 11 & 50 & 80 \\
\hline 12 & 60 & 70 \\
\hline Rata-rata & $\mathbf{5 0 , 8 3}$ & $\mathbf{8 0 , 8 3}$ \\
\hline
\end{tabular}

Sumber : Data Diolah (2017) 
Nilai pre test dan post test jika dilakukan analisis uji beda T-test sampel berhubungan adalah sebagai berikut:

Tabel 2. Hasil Uji Beda T test Berhubungan

Paired Samples Statistics

\begin{tabular}{|c|c|c|c|c|c|}
\hline & & Mean & $\mathrm{N}$ & $\begin{array}{l}\text { Std. } \\
\text { Devi } \\
\text { ation }\end{array}$ & $\begin{array}{l}\text { Std. Error } \\
\text { Mean }\end{array}$ \\
\hline \multirow{2}{*}{ Pair 1} & & $\begin{array}{r}50,833 \\
3\end{array}$ & 12 & $\begin{array}{r}18,3 \\
1955\end{array}$ & 5,28840 \\
\hline & postest & $\begin{array}{r}80,833 \\
3\end{array}$ & 12 & $\begin{array}{r}11,6 \\
4500 \\
\end{array}$ & 3,36162 \\
\hline
\end{tabular}

\begin{tabular}{|lc|r|r|c|}
\hline \multicolumn{6}{|c|}{ Paired Samples Correlations } \\
\hline & $\mathrm{N}$ & Correlation & Sig. \\
\hline Pair 1 & $\begin{array}{c}\text { pretest \& } \\
\text { postest }\end{array}$ & 12 &, 678 &, 015 \\
\hline
\end{tabular}

Paired Samples Test

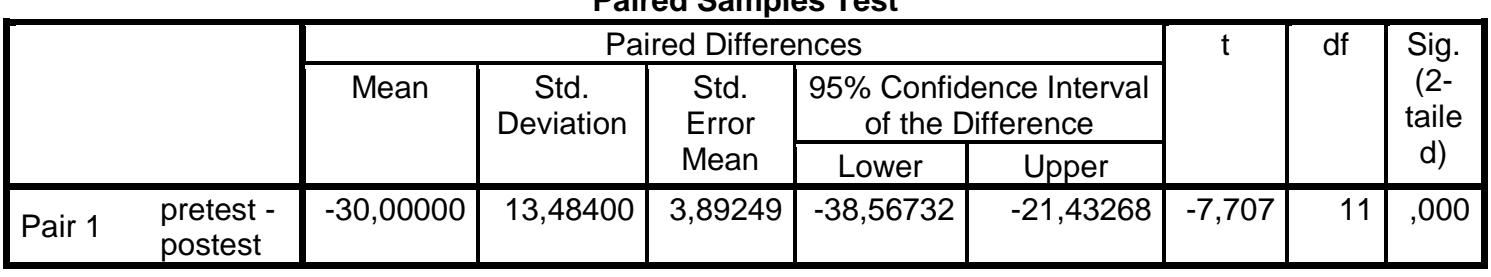

Sumber : Output SPSS

Berdasarkan tabel 2 di atas terlihat bahwa nilai hasil uji $\mathrm{T}$ Test menghasilkan nilai rata-rata pre test sebesar 50,83 dan rata-rata nilai post test sebesar 80,83. Selain itu, hasil uji T test berhubungan juga menghasilkan nilai signifikansi $0,000 . \quad$ Nilai signifikansi kurang dari 0,05 yang artinya. Hal ini mengindikasikan bahwa secara statistik terdapat perbedaan ratarata antara nilai pre test dan nilai post test pelatihan.

Berdasarkan temuan di atas, maka dapat di simpulkan bahwa pelatihan ekonomi syariah yang diikuti oleh Guru MGMP Akuntansi SMK di kabupaten Demak mampu meningkatkan pemahaman guru terhadap konsep ekonomi syariah, operasionalisasi perbankan syariah dan akuntansi syariah. Jika dihubungkan dengan masalah yang dihadapi mitra, maka metode pelatihan yang dilakukan oleh dosen yang memiliki kompetensi ekonomi syariah kepada guru SMK mampu mengurangi permasalahan mitra (guru) yang memiliki keterbatasan dalam pengajaran pada program studi perbankan syariah. 


\section{KESIMPULAN DAN SARAN}

Pelatihan yang dilakukan oleh dosen yang memiliki bidang keahlian ekonomi syariah kepada guru SMK menghasilkan nilai pre test dan post test yang berbeda. Hasil ini menyimpulkan bahwa melalui pelatihan, mampu meningkatkan kompetensi guru dan selanjutnya dapat memberikan salah satu solusi terkait masalah kurangnya kompetensi guru.

Namun demikian, pelatihan yang melibatkan dosen dan guru belum secara optimal memberikan kompetensi yang lengkap bagi guru. Hal ini dikarenakan, Standar kompetensi SMK adalah memiliki keahlian operasional terhadap program studi, sehingga pelibatan dari pelaku perbankan syariah dalam pelatihan sangat dibutuhkan untuk melengkapi kemampuan operasional secara teknis pada bank syariah.

\section{DAFTAR PUSTAKA}

Anisykurlillah,Indah; $\quad$ Fachrurrozie; Mukhibad, Hasan. 2015. A Financial Report Model for Traditional Market Traders to Increase

Mudharabah
Financing in Baitul Maal Wattamwil (BMT). Review Integrative Business Economics Research, 5 (1), 219 - 229

Amalia dan Al Arif, 2013. Peta Potensi SDM Ekonomi Islam pada PTAI dan PTU: Analisis Kurikulum, Model Pembelajaran dan Hubungannya dengan Kebutuhan SDM pada Industri Keuangan Syariah di Indonesiahttp://www.ekonomisy ariah.org/wpcontent/uploads/2017/01/FRPSEuis-Amalia.pdf. Di unduh tanggal 13 Februari 2017

Asian Development Bank (2017). Islamic Finance. http://www.adb.org/sectors/finan ce/islamic-finance. Di unduh tanggal 13 Februari 2017

Bank Indonesia. 2015. Statistik Perbankan Syariah Indonesia.

Iqbal dan Mirakhor (2013). Islam's perspective on financial inclusion." In Economic Development and Islamic Finance, Zamir Iqbal, and Abbas Mirakhor (eds.) The World Bank.

Khan, Ajaz Ahmed. 2008. "Islamic Microfinance Theory, Policy, and Practice," Islamic Relief, February

Kustin, Bridge. (2015). Islamic (Micro) Finance : Culture, Context, Promise, Challenges. 